\title{
GAMBARAN YANG MEMPENGARUHI FETAL DISTRESS PADA SECTIO CAESAREA DI RSUD BANYUMAS
}

\author{
Daryanti, Happy Dwi Aprilina \\ Fakultas Ilmu Kesehatan Universitas Muhammadiyah Purwokerto \\ Jl. KH. Ahmad Dahlan, Purwokerto Kembar Banyumas, Jawa Tengah, Indonesia \\ happydwiaprilina@gmail.com
}

\begin{abstract}
Abstrak
Fetal distres suatu kondisi yang sangat berbahaya bagi janin karena dapat memicu terjadinya berbagai macam penyakit berbahaya. Fetal distress merupakan faktor penyebab dimana dilakukan tindakan section casearea. Tujuan mengetahui fetal distress pada sectio caesarea di RSUD Banyumas. Jenis penelitian merupakan Analisis Dokumentasi menggunakan pendekatan Retrospektif. Menggunakan teknik total sampling sebanyak 80 responden. Analisis menggunakan deskriptif statistik. Responden sebagian besar reponden berusia reproduktif sebanyak 63 responden $(78,8 \%)$, multipara sebanyak 42 responden $(52,5 \%)$, ibu rumah tangga sebanyak 67 responden $(83,8 \%)$, usia kehamilan cukup bulan sebanyak 68 responden $(85,0 \%)$ dan paling banyak pendidikan SLTP sebanyak 29 responden (36,3\%). Pasien masuk dengan diagnosa masuk paling banyak adalah partus tidak maju sebanyak 25 responden $(31,3 \%)$. Fetal distres di rumah sakit paling banyak yang disebabkan lima kasus adalah partus tidak maju, ketuban pecah dini, umur kehamilan PEB, dan DJJ ireguler maupun oligohidromion.
\end{abstract}

Kata Kunci: Fetal Distress, Sectio Caesarea

\begin{abstract}
Fetal distress is a disease that is very dangerous for the fetus because it can dispute a dangerous disease. It is a causative factor in which sectio caesarea is taken. Objective To fetal distress in section caesarea in RSUD (Regional Public Hospital) Banyumas. This research is was a Documentation Analysis using a Retrospective approach. The sampling technique with a total sampling of 80 respondents. The analysis was statistical descriptive. Most of the respondents 63 (78.8\%) are in the reproductive period, 42 (52.5\%) respondents are multipara, 67 (83.8\%) respondents are housewives, 68 (85,0\%) respondents are in gestational age, and 29 (36.3\%) respondents are graduated from Junior High School. Most of the inpatients, 25 (31.3\%) respondents are patients with undeveloped parturition. Fetal distress in the hospital is mostly caused by five cases, namely undeveloped parturition, early water break, gestational age of PEB, and irregular DJJ as well as oligohydromion.
\end{abstract}

Keywords: Fetal distress, Sectio Caesarea

\section{PENDAHULUAN}

Salah satu tindakan medis membantu persalinan yang dilakukan ketika terdapat masalah kesehatan pada ibu atau kondisi janin yaitu dengan sectio caesarea (SC). Angka kejadian tindakan section caesarea di dunia setiap tahunnya mengalami peningkatan.

Berdasarkan Riskesdas 2013 menunjukan kejadian persalinan tindakan SC di Indonesia mencapai 9,8 \% dari jumlah persalinan, kejadian tertinggi di DKI Jakarta

Corresponding author:

Happy Dwi Aprilina

happydwiaprilina@gmail.com 
sebanyak 19,9\%, dan tindakan SC paling sedikit di Sulawesi Tenggara dengan jumlah 3,3\% dari jumlah persalinan (Maryani, 2017). Kejadian operasi SC di Jawa Tengah mencapai $32.2 \%$ berdasarkan data Litbangkes tahun 2012 (Wirakhmi, 2016). Sedangkan di RSUD Banyumas tindakan operasi ada 8,6\% dari semua tindakan persalinan tahun 2018 (Data RSUD Banyumas, 2019).

Operasi caesar hanya dilakukan apabila proses persalinan normal tidak mungkin untuk dilakukan. Ketidakmampuan melahirkan normal pada ibu disebabkan berbagai faktor, baik faktor dari ibu ataupun janin yang dikandungnya (Wirawan, 2016). Menurut Wirawan (2017) pertimbangan seorang dokter sebelum memutuskan ibu dilakukan operasi yaitu kehamilan kembar, ibu dengan penyakit berat, tekanan darah tinggi, bentuk panggul sempit, masalah dengan plasenta dan posisi bayi.

Hasil penelitian Muhammad (2016) menunjukkan bahwa indikasi yang menyebabkan kejadian tindakan sectio caesarea yaitu fetal dengan kelainan letak sebanyak 18 (20,7\%), paling tinggi didapatkan karena adanya gawat janin sebanyak $25(28,7 \%)$ dan paling rendah kelahiran bayi kembar sebanyak 2 (2,3\%). Gawat janin / fetal distres adalah salah satu indikasi yang sering ditemui ibu dengan persalinan sectio caesarea.

Hasil penelitian Kristiani (2017) menunjukkan bahwa 2 pasien yang dilakukan tindakan sectio caesaria disebabkan fetal distress. Dilakukannya tindakan tersebut bertujuan untuk menyelamatkan janin dari hipoksia. Kematian janin dalam kandungan dapat disebabkan karena hipoksia. Penelitian menunjukkan bahwa persalinan dengan sectio cesarea kondisi fetal kondisi fetal distress sebanyak $4,1 \%$ dan seksio sesarea emergensi kondisi fetal distress sebanyak 22,6\%.

Dari hasil studi pendahuluan yang dilaksanakan di RSUD Banyumas diketahui angka kejadian sectio caesarea atas indikasi fetal distress bulan Januari-Desember 2018 sebanyak 80 kasus. Tujuan penelitian yaitu mengetahui penelitian tentang gambaran Fetal Distress Pada Sectio Caesarea di RSUD Banyumas".

\section{METODE PENELITIAN}

Desain penelitian Analisis Dokumentasi dengan pendekatan Retrospektif. Penelitian dilakukan di RSUD Banyumas pada November 2019. Populasi seluruh ibu yang bersalin dengan tindakan Sectio caesarea pada Januari-Desember 2018 sebanyak 80 orang yang tercatat di buku register RSUD Banyumas. Pengambilan sampel dengan teknik total sampling sebanyak 80 responden, kriteria inklusi yaitu data pasien bulan Januari-Desember 2018 dan pasien dengan tindakan operasi Sectio caesarea. Sedangkan kriteria eksklusi yaitu data tidak lengkap (sesuai dengan variabel penelitian). Pengambilan data menggunakan lembar observasi. Analisis menggunakan destkriptif statistik.

\section{HASIL}

1. Karakteristik responden ibu yang melahirkan sectio caesarea berdasarkan usia, paritas, pendidikan dan pekerjaan,usia kehamilan ibu di RSUD Banyumas.

Tabel 1

Karakteristik Responden Ibu Yang Melahirkan Sectio Caesarea Berdasarkan Usia, Paritas, Pendidikan,Pekerjaan,Dan Usia Kehamilan Ibu di RSUD Banyumas.

\begin{tabular}{lcc}
\hline Karakteristik responden & Frekuensi & Persentasi (\%) \\
\hline Umur & & \\
Usia reproduktif (20-35 tahun) & 63 & 78.8 \\
Usia resiko tinggi (<20 atau > 35 tahun) & 17 & 21.3 \\
Paritas & & \\
Primipara & 35 & 43.8 \\
Multipara & 42 & 52.5 \\
\hline
\end{tabular}




\begin{tabular}{lcc}
\hline Grande multipara & 3 & 3.8 \\
Pendidikan & & \\
SD & 19 & 23.8 \\
SLTP & 29 & 32.5 \\
SLTA & 26 & 36.3 \\
Diploma & 1 & 1.3 \\
Sarjana & 5 & 6.3 \\
Pekerjaan & & \\
Bidan & 1 & 1.3 \\
Dokter & 1 & 1.3 \\
Guru & 1 & 1.3 \\
Irt & 67 & 83.8 \\
Pedagang & 1 & 1.3 \\
Swasta & 9 & 11.3 \\
Usia & & \\
Usia kehamilan cukup bulan & 68 & 85.0 \\
Usia kehamilan kurang bulan & 9 & 11.3 \\
Usia kehamilan lewat bulan & 3 & 3.8 \\
$\quad$ Total & 80 & 100 \\
\hline
\end{tabular}

Tabel 1 diatas menunjukkan sebagian besar reponden berusia reproduktif sebanyak 63 $(78,8 \%)$ dan $17(21,3 \%)$ berusia dalam kategori risiko tinggi. Paritas responden sebagian besar dalam kategori multipara sebanyak 42 (52,5\%), pendidikan paling banyak SLTP sebanyak 29 $(36,3 \%)$, pekerjaan mayoritas ibu rumah tangga sebanyak 67 (83,8\%), usia kehamilan sebagian besar usia kehamilan cukup bulan sebanyak $68(85,0 \%)$.

2. Fetal distres pada pasien yang dilakukan sectio caesarea di RSUD Banyumas.

Tabel 2

Fetal distres pada pasien yang dilakukan sectio caesarea di RSUD Banyumas

\begin{tabular}{lcc}
\hline Diagnosa masuk & Frekuensi & Persentasi (\%) \\
\hline Anemia & 2 & 2.5 \\
DJJ Ireguler & 3 & 3.8 \\
Gemeli & 2 & 2.5 \\
Gestasional hipertensi & 1 & 1.3 \\
Kegagalan induksi & 1 & 1.3 \\
KPD & 18 & 22.5 \\
Oligohidromion & 3 & 3.8 \\
Partus prematurus imminens & 1 & 1.3 \\
Partus tidak maju & 25 & 31.3 \\
PEB & 9 & 11.3 \\
DKP & 1 & 1.3 \\
Pre eklamsi ringan & 1 & 1.3 \\
Presentasi majemuk & 1 & 1.3 \\
Tali pusat pendek & 1 & 1.3 \\
Umur kehamilan & 11 & 13.8 \\
Total & 80 & 100.0 \\
\hline
\end{tabular}

Tabel 2 menunjukkan bahwa pasien masuk dengan diagnose masuk paling banyak adalah partus tidak maju sebanyak 25 responden $(31,3 \%)$ dan paling sedikit adalah gastasional hipertensi, kegagalan induksi, partus prematurus imminens, pre eklamsi, pre eklamsi ringan, presentasi majemuk dan tali pusat pendek masing-masing sebanyak 1 responden $(1,3 \%)$.

\section{PEMBAHASAN}

1. Karakteristik responden ibu yang melahirkan sectio caesarea berdasarkan usia, paritas, pendidikan dan pekerjaan,usia kehamilan ibu di RSUD Banyumas.

a. Usia 
Hasil penelitian menunjukkan sebagian besar reponden berusia reproduktif. Pada usia ini responden secara kematangan reproduksi sudah siap untuk pembuahan. Selain itu, pada usia tersebut ibu dalam kategori aman dalam menjalani kehamilan dan persalinan. Hasil penelitian tersebut didukung dengan penelitian Corneles (2015) menyatakan bahwa usia 20-35 tahun adalah usia yang matang karena sistem reproduksi siap untuk dibuahi.

Resiko tinggi usia Ibu yang hamil memiliki peluang komplikasi pada saat hamil ataupun melahirkan. Hasil penelitian Beirut et. al. (2017) menunjukkan bahwa komplikasi dengan peluang tertinggi di antara wanita, usia 11-18 tahun, dibandingkan dengan wanita berusia 25-29 tahun. Ibu hamil usia kurang dari 20 tahun dan lebih dari 40 tahun memiliki risiko tinggi untuk menyebabkan gawat janin. Umur seorang ibu juga memiliki dampak pada pertumbuhan dan perkembangan janin yang buru.

Zanah (2015) menjelaskan bahwa keadaan hamil, bersalin, nifas dan bayi dipengaruhi oleh umur ibu yang berperan dalam kesehatan maternal. Proses reproduksi yang baik dan jarang terjadi penyulit kehamilan dan persalinan pada usia rentang 20 sampai 35 tahun. Ibu hamil usia kurang dari 20 tahun maupun lebih dari 35 tahun menjadi salah satu penyebab penyulit kehamilan. Usia ibu hamil kurang dari 20 tahun, memiliki tubuh yang belum siap menghadapi kehamilan, persalinan, nifas serta merawat bayinya, sebaliknya usia ibu hamil lebih dari 35 tahun memiliki resiko seperti kelainan bawaan dan penyulit saat persalinan yang disebabkan adanya kelainan jaringan otot rahim untuk menerima kehamilan.

b. Paritas
Hasil penelitian menunjukkan paritas responden sebagian besar multipara. Hasil tersebut menjelaskan bahwa responden sudah memiliki pengalaman kehamilan dan persalinan. Pengalaman yang dimiliki oleh seorang ibu pada masa kehamilan dan persalinan berperan penting dalam memahami dan pengetahuan permasalahan kesehatan selama hamil dan bersalin. Menurut Corneles (2015) bahwa ibu yang belum berpengalaman dalam kehamilan sebelumnya sehingga dapat mempengaruhi pengetahuannya. Ibu yang baru pertama hamil belum mendapatkan informasi tentang risiko tinggi dalam kehamilan, sehingga ibu cenderung memiliki pengetahuan yang rendah.

Menurut Hipson (2016) bahwa paritas 2-3 memiliki resiko yang rendah dari aspek kematian maternal. Paritas lebih dari 3 memiliki resiko yang tinggi pada kematian maternal. Semakin banyak paritas, maka resiko kematian maternal tinggi. Resiko kematian maternal yang disebabkan oleh banyaknya paritas dapat dicegah melalui keluarga berencana. Hal tersebut menjelaskan bahwa paritas memiliki peran penting dalam menentukan keselamatan ibu dan bayi.

c. Pendidikan

Hasil penelitian menunjukkan pendidikan paling banyak SLTP. Pendidikan merupakan faktor penting menentukan perilaku kesehatan seseorang. Tingkat pendidikan yang tinggi seseorang maka semakin baik perilaku seseorang dalam menjaga kesehatan. Pendidikan seseorang yang tinggi dapat mendukung atau mempengaruhi tingkat pengetahuanya. Seorang yang memiliki pendidikan semakin tinggi maka semakin tinggi pengetahuan seseorang. Pendidikan yang tinggi mempermudah ibu memperoleh informasi baru sehingga 
tidak akan acuh atau tidak peduli terhadap informasi kesehatan sedangkan semakin rendah pendidikan maka pengetahuan pun sangat terbatas sehingga kurang peduli terhadap program kesehatan.

Noviana (2018) menjelaskan bahwa seorang yang berpendidikan tinggi mudah untuk menerima perubahan, dan terbuka dalam menerima informasi. Ibu yang terbuka akan mudah menyerap informasi melalui berbagai media. Ibu yang memperoleh informasi lebih banyak, maka ibu dapat menilai pandangan tentang kesehatan yang benar atau kurang tepat. Salah satu contohnya adalah pandangan ibu yang sering datang berobat hanya ketika ada keluhan.

Hispon (2016) menjelaskan bahwa tingkah laku manusia dapat dipengaruhi oleh tingkat pendidikan seseoarang. Hal ini karena tingkat pendidikan merupakan salah satu aspek sosial, tingkat pendidikan mempengaruhi ibu dalam melakukan respon terhadap sesuatu atau rangsangan dari luar yang lebih rasional. Prawirohardjo, (2010) menjelaskan bahwa pendidikan merupakan determinan konsektual dalam morbiditas dan mortalitas maternal.

d. Pekerjaan

Hasil penelitian menunjukkan paling banyak bekerja sebagai ibu rumah tangga. Corneles (2015) menjelaskan bahwa status pekerjaan ibu berpengaruh terhadap kejadian hamil beresiko. Ibu yang bekerja sebagai ibu rumah tangga cenderung kurang menyerap informasi kesehatan jika dibandingkan ibu yang bekerja diluar rumah. Hal tersebut juga didukung pendapat Sulistyawati (2009) dalam Budiman (2017) bahwa ibu bekerja memiliki lebih banyak peluang untuk mendapatkan informasi tentang kondisi kesehatannya. Oleh karena itu, ibu yang bekerja memiliki banyak informasi dibandingkan ibu yang tidak bekerja.

Selain itu, pekerjaan juga merupakan salah satu faktor dalam menentukan untuk minat seorang ibu hamil dalam mengakses pelayanan kesehatan. Kondisi tersebut menyebabkan ibu hamil mengalami risiko kehamilan dan persalinan. Menurut Sari (2014) bahwa ibu dengan social ekonomi yang rendah berpotensi mengalami kehamilan yang beresiko dan kesulitan untuk mengakses pelayanan kesehatan berbeda dengan ibu dengan social ekonomi menengah keatas.

e. Usia kehamilan

Usia kehamilan responden sebagian besar usia kehamilan cukup bulan. Bayi cukup bulan pada usia kehamilan 37-38 minggu, bayi prematur lahir sebelum 37 minggu. Bayi lahir pada usia kehamilan 37 minggu beresiko kematian $2 \mathrm{x}$ lebih besar bila dibandingkan bayi lahir usia kehamilan 40 minggu (Anna, 2011).

Selain itu, usia kehamilan juga memiliki risiko menyebabkan kehamilan yang berisiko bahkan sampai menyebabkan kematian pada bayi. Menurut Ahmad (2016) menyatakan bahwa factor resiko terjadinya abortus di RS adalah usia kehamilan. Ibu hamil yang memasuki trimester I mempunyai risiko abortus 19.7 kali lebih besar dibandingkan dengan ibu yang sudah melewati usia kehamilan trimester I.

2. Fetal distres pada pasien yang dilakukan sectio caesarea di RSUD Banyumas.

Berdasarkan hasil penelitian menunjukkan bahwa gambaran dimana pasien masuk dengan diagnose masuk paling banyak adalah partus tidak maju dan paling sedikit adalah gastasional hipertensi, kegagalan induksi, partus prematurus imminens, pre eklamsi, pre 
eklamsi ringan, presentasi majemuk dan tali pusat pendek masing. Partus tidak maju merupakan salah satu faktor yang menyebabkan persalinan dilakukan dengan tindakan SC. Partus lama juga merupakan bagian dari faktor penyebab gawat janin atau fetal distress. Menurut Prawirahadjo (2009) bahwa proses persalinan lama selalu memberikan dampak yang buruk dan penyulit bagi ibu dan janin yang sedang dikandungnya. Janin dalam rahim menjadi dalam situasi berbahaya karena kontraksi rahim terjadi 24 jam yang dapat mengganggu aliran darah menuju janin.

Menurut Kemenkes (2018) faktor penyebab terjadinya gawat janin yaitu persalinan lama, perdarahan, kejang, obat perangsang kontraksi rahim, infeksi, kehamilan prematur dan post matur, ketuban pecah lama dan tali pusat menumbung. Menurut Sumelung (2014) bahwa indikasi yang sering menyebabkan kejadian sectio caesarea yaitu gawat janin sebanyak 52 responden $(31,14 \%)$. Gawat janin merupakan salah satu indikasi yang sering terjadi pada ibu persalinan sectio caesarea, jika ibu dengan gawat janin tetap melakukan partus normal maka akan membahayakan keselamatan ibu dan bayi.

Menurut Adrian (2019) bahwa persalinan yang terlalu lama bukan hanya dapat menguras tenaga, tapi juga berbahaya bagi kondisi ibu dan janin di dalam kandungan. Proses persalinan yang macet ini bisa menyebabkan ibu kelelahan, serta meningkatkan risiko bayi mengalami gawat janin, cedera, dan infeksi. Kondisi persalinan lama dapat menyebabkan kurangnya pasokan oksigen pada janin sehingga bersiko menyebabkan fetal distress. Kemenkes (2018) bahwa fetal distress merupakan kondisi janin mengalami kekurangan menerima $\mathrm{O} 2$, sehingga janin mengalami sesak.

Pernyataan diatas juga dikuatkan

pendapat Reiter dan Walsh (2010) menyebutkan bahwa persalinan yang berlangsung lama memiliki risiko untuk menyebabkan kejadian fetal distress pada bayi. Federico dan Staton (2018) bahwa persalinan yang lama dan persalinan yang sulit menempatkan ibu pada risiko bahaya serius, tetapi keadaan ini juga dapat menciptakan gawat janin yang akan berefek pada jangka panjang bagi kesehatan dan perkembangan bayi baru lahir itu sediri. Ada sejumlah cacat jangka panjang yang bisa diakibatkan oleh gawat janin.

\section{KESIMPULAN}

Pasien fetal distress sebagian besar reponden berusia reproduktif, multipara, ibu rumah tangga, usia kehamilan cukup bulan, SLTP. Diagnosa masuk pasien dengan fetal distress paling banyak yaitu partus tidak maju. Saran:

1. Bagi Perawat Rumah Sakit

Diharapkan dalam pengisian data dokumentasi asuhan keperawatan untuk selalu mengecek kembali kelengkapan data sebelum diberikan pada bagia data rekam medis.

2. Bagi Peneliti Selanjutnya

Diharapkan penelitian ini dapat diteliti lebih lanjut oleh peneliti lain menggunakan metode penelitian yang berbeda yaitu desain korelasi untuk mengetahui variabel apa yang berhubungan dengan kejadian fetal distress.

\section{DAFTAR PUSTAKA}

Adrian. (2018). Waspadai Perdarahan Antepartum pada Masa Kehamilan. Diakses pada 15 September 2019 dari https://www.alodokter.com/waspadaiperdarahan-antepartum-pada-masakehamilan

Ahmad. (2016). Analisis Faktor Risiko Usia Kehamilan Dan Paritas Terhadap Kejadian Abortus. Jurnal Al-Maiyyah, $9(1)$.

Anna. (2011). Hindari Persalinan Sebelum 39 Minggu Kehamilan. Diakses pada 22 
Januari $2020 \quad$ dari https://nasional.kompas.com/read/201 1/05/30/1630982/hindari.

persalinan.sebelum.39.minggu.kehami lan.

Budiman. (2017). Hubungan Tingkat Pendidikan, Pekerjaan, Status Ekonomi Dengan Paritas Di Puskesmas Bahu Manado. e-Journal Keperawatan(e-Kp), 5 (1).

Biuret et. al. (2017). Maternal age and risk of labor and delivery complications. Matern Child Health Journal, 19 (6).

Corneles. (2015). Hubungan Tingkat Pendidikan Dengan Pengetahuan Ibu Hamil Tentang Kehamilan Risiko Tinggi. Jurnal Ilmiah Bidan, 3 (2).

Data RSUD Banyumas. (2019). Profil Kesehatan Tahun 2018. RSUD Banyumas

Federico dan Staton. (2018). Fetal Distress And Long-Term Disabilities In Children. Diakses pada 2 Januari 20120 dari https://www.sfspa.com/fetal-distressand-long-term-disabilities-in-children/

Hipson. (2016). Hubungan antara umur, paritas dan pendidikan ibu dengan kejadian eklampsia di Rumah Sakit Muhammadiyah Palembang. Rakernas Aipkema "Temu Ilmiah Hasil Penelitian dan Pengabdian Masyarakat"

Kemenkes. (2018). Gawat Janin. Diakess pada 2 Januari 2020 dari http://www.yankes.kemkes.go.id/read -gawat-janin-5251.html
Kristiani. (2017). Faktor-Faktor Yang Berhubungan Dengan Pengambilan Keputusan Persalinan Sc Pada Ibu Di Rsia Melati Husada Malang. Nursing News, 2 (3).

Maryani. (2017). Determinan Persalinan Seksio Sesarea Di RSUD Wates Kulon Progo Tahun 2016. Naskah Publikasi. Universitas 'Aisyiyah

Muhammad. (2016). Karakteristik Ibu Yang Mengalami Persalinan Dengan Sectio Caesarea Di Rumah Sakit Umum Daerah Moewardi Surakarta Tahun 2014. Skripsi. Universitas Muhammadiyah Surakarta

Noviana. (2018). Hubungan Usia Dan Tingkat Pendidikan Ibu Hamil Terhadap Kepatuhan Melaksanakan Ante Natal Care (ANC) Di RSI Pekajangan. Naskah Publikasi.

Prawirohardjo, S. (2009). Pelayanan Kesehatan Maternal Dan Neonatal. Jakarta: PT Bina Pustaka.

Reiter dan Walsh. (2010). What Signs Indicate My Baby Is In Distress? How Is Fetal Distress Treated?. Dikases pada 20 Januari $2020 \quad$ dari https://www.abclawcenters.com/frequ ently-asked-questions/what-are-somesigns-that-my-baby-is-in-distress/

Sari. (2014). Faktor-Faktor Yang Berpengaruh Terhadap Risiko Kehamilan "4 Terlalu (4-T)" Pada Wanita Usia 1059 Tahun (Analisis RISKESDAS 2010). Media Litbangkes, 24 (3).

Sumelung. (2014). Faktor - Faktor Yang Berperan Meningkatnya Angka Kejadian Sectio Caesarea Di Rumah Sakit Umum Daerah Liun Kendage Tahunan. Ejournal keperawatan (e$K p), 2(1)$. 
Adi Husada Nursing Journal, Vol 6 No 1, Juni 2020/ Hal. 66

Wirawan. (2016). @blogdokter. Jakarta: Noura Books.

Wirawan. (2017). Blog Dokter: Kesehatan Wanita (Snackbook). Jakarta: Noura Books.
Zanah. (2015). Faktor-Faktor Yang Berhubungan Dengan Persalinan Sectio Caesarea Di RSUD Panembahan Senopati Bantul Tahun 2015. Artikel Ilmiah. 